\title{
ASPEK FINANSIAL DAN KELEMBAGAAN SISTEM USAHA PERIKANAN (SUP) PENANGKAPAN IKAN PATIN DI INDONESIA
}

\author{
Zahri Nasution"), Elly Reswati') Jojo Subagja") dan Sonny Koeshendrajana*)
}

\begin{abstract}
ABSTRAK
Riset yang bertujuan mengevaluasi aspek finansial dan kelembagaan sistem usaha perikanan penangkapan ikan patin yang ada di masyarakat nelayan termasuk kebijakan pemerintah dan permasalahannya telah dilakukan pada tahun 2002. Riset dilaksanakan pada beberapa lokasi di Jawa Barat, Sumatera Selatan, Jambi, dan Kalimantan Selatan menggunakan metoda survai. Survai dilakukan untuk mengumpulkan data teknologi, ekonomi dan kelembagaan sistem usaha yang dipandu menggunakan daftar topik pertanyaan dan dikumpulkan dengan cara wawancara langsung terhadap responden. Hasil riset menunjukkan bahwa nelayan menangkap ikan patin menggunakan alat tangkap jaring, jala dan bubu yang tergolong sederhana. Usaha penangkapan ikan patin yang mereka laksanakan secara finansial cukup menguntungkan meskipun belum ada kelembagaan yang mengorganisasi mereka terutama dari segi pemasaran hasil tangkapan. Permasalahan yang dihadapi antara lain adalah kurangnya modal untuk pembelian sarana penangkapan baik berupa perahu maupun alat tangkap. Oleh karena itu diperlukan bantuan modal dan pengorganisasian nelayan.
\end{abstract}

ABSTRACT: Financial and institutional aspects of the catfish (Pangasius sp) capture fishery in Indonesia. By: Zahri Nasution, Elly Reswati, Jojo Subagja and Sonny Koeshendrajana

An investigation to evaluate the financial and institutional aspects of catfish capture fisheries and its related problems and policies were conducted in the 2002. Research was carried out at several location at West Java, South Sumatra, Jambi and South Kalimantan Province using survey method. The method combined with a topical questionaires list was used to collect data on technology, economic and institutional aspects. The result showed that catfish fishers operate a simple form of gill net, set net and pot trap in their activity. The activities were financially profitable though they were lack of institution which is responsible to organize their fish caught. Problems faced by the fishers were in turns of capital assets, such as boat and fishing gear. Consequently, financial aid and proper fishers organization are required.

KEYWORDS: financial, institution, capture fishery, catfish, Indonesia

\section{PENDAHULUAN}

Kegiatan usaha perikanan penangkapan masih sangat dominan bila dibandingkan dengan kegiatan usaha perikanan budidaya. Hal ini terbukti antara lain dari produksi ikan air tawar yang dihasilkan dari usaha perikanan budidaya yang hanya memberikan kontribusi sekitar $15-20 \%$ dari total produksi ikan air tawar di Indonesia. Namun demikian, produksi ikan yang berasal dari hasil tangkapan di beberapa perairan Indonesia memperlihatkan penurunan. Penurunan tersebut terutama sebagai akibat dari praktek penangkapan yang intensif tanpa memperhatikan kelestariannya dan sebagai akibat tekanan beberapa sektor pengguna perairan yang mengakibatkan pencemaran serta kerusakan habitat perikanan.

Pada sisi lain, telah diketahui bahwa produksi ikan yang dapat dihasilkan oleh kegiatan usaha penangkapan sangat tergantung kepada ketersediaan stok ikan di alam serta pola pemanfaatan dan pengelolaannya (Koeshendrajana, 1997; Aeron-Thomas et al., 1998).

Pada era krisis ekonomi yang terjadi dewasa ini ternyata hanya sektor agribisnis yang mampu mencapai pertumbuhan positif, bahkan menjadi andalan bagi kebangkitan ekonomi Indonesia (Saragih, 2001a). Keunggulan komparatif bidang perikanan dalam bentuk biodiversitas sumberdaya alam, sumberdaya manusia, dan peluang pasar domestik dan internasional masih terbuka luas (Goenadi, 2000).

Tantangan utama dalam agribisnis adalah mengubah keunggulan komparatif menjadi keunggulan kompetitif dalam membentuk suatu usaha agribisnis yang tangguh (Saragih, 2001b). Untuk mencapai

\footnotetext{
Peneliti pada Pusat Riset Pengolahan Produk dan Sosial Ekonomi Kelautan dan Perikanan

- Peneliti pada Balai Riset Perikanan Budidaya Air Tawar, PRPB
} 
target itu diperlukan antara lain adalah penggunaan teknologi dan manajemen yang unggul dalam usaha yang dilakukan (Saragih, 2001a). Dengan demikian, faktor-faktor yang terkait dengan hal tersebut adalah peningkatan produktivitas dan kualitas, efisiensi dalam manajemen, serta konservasi sumberdaya perikanan. Faktor-faktor ini secara keseluruhan akan meningkatkan daya saing usaha agribisnis.

Ikan patin merupakan komoditas yang bernilai ekonomis penting terutama untuk wilayah Propinsi Sumatera Selatan, Jambi, Kalimantan Selatan dan Jawa Barat. Ikan patin tersebut selain diperoleh dari hasil budidaya juga masih banyak diantaranya yang dihasilkan dari hasil tangkapan dari alam. Hasil survai pendahuluan pada tahun 2001 menunjukkan bahwa penangkapan ikan patin dilakukan nelayan di sungai dengan sistem penangkapan menggunakan alat tangkap berupa jaring (gill-net). Alat tangkap ini dipasang kearah perairan yang diperkirakan ada ikannya

Selama ini data dan informasi yang berkaitan dengan aspek sosial ekonomi dan kelembagaan sistem usaha perikanan penangkapan ikan patin belum banyak diungkap dan dimanfaatkan bagi pengembangannya lebih lanjut. Hasil riset terhadap ikan patin selama ini, baik yang dilakukan melalui kerjasama Orstom/IRD, bantuan luar negeri maupun berdasarkan dana lokal lebih ditekankan pada aspek biologi (Hadie dan Hadie, 2000). Oleh karena itu riset yang berhubungan dengan aspek finansial dan kelembagaan sistem usaha perikanan penangkapan ikan patin perlu dilakukan.

\section{METODE}

Riset dilaksanakan pada beberapa lokasi yang dominan memiliki perairan umum yang diperkirakan terdapat usaha penangkapan ikan patin yaitu Jawa Barat, Sumatera Selatan, Jambi dan Kalimantan Selatan. Lokasi terpilih diharapkan menggambarkan berbagai sistem usaha perikanan penangkapan ikan patin. Pemilihan responden dilakukan dengan cara penarikan contoh acak sederhana (simple random sampling) (Cochran, 1977) dengan pertimbangan bahwa terdapat homogenitas yang tinggi dalam sistem usaha perikanan penangkapan ikan patin yang dilaksanakan nelayan di setiap lokasi riset.

Data primer dikumpulkan pada tingkat nelayan meliputi aspek teknologi dan ekonomi usaha penangkapan, hasil tangkapan dan kelembagaan nelayan. Data sekunder yang menyangkut kebijakan yang berhubungan dengan sistem usaha penangkapan ikan patin di lokasi riset dikumpulkan dari instansi Dinas Perikanan setempat. Pengumpulan data dilaksanakan menggunakan metoda survai dan dilakukan antara bulan April hingga Nopember 2002 Survai ini dilakukan menggunakan panduan daftar pertanyaan yang terbuka dan dikumpulkan dengan cara wawancara langsung terhadap responden (Singarimbun dan Effendi, 1989). Nelayan dalam hal ini adalah mereka yang melaksanakan penangkapan ikan dan mengelola usaha perikanan penangkapan ikan patin.

Untuk menggambarkan sistem usaha perikanan penangkapan ikan patin maka data primer dan sekunder dianalisis secara deskriptif dan diinterpretasikan menggunakan metode logik. Metode logik adalah cara menalar dimana data diamati dan dipilah-pilah, buktinya dicari dan dipertimbangkan. dianalisis dan kemudian kesimpulan diambil (Nazir 1988). Kemudian analisis finansial dilihat berdasarkan kemampuan usaha tersebut untuk menghasilkan sejumlah penerimaan dari sejumlah biaya yang dikeluarkan yang menggunakan indikator RC Ratio (Return Cost Ratio)

\section{HASIL DAN BAHASAN}

\section{Teknologi dan Hasil Penangkapan Ikan Patin}

Teknologi penangkapan ikan patin pada seluruh wilayah riset dapat dikategorikan sebagai teknologi sederhana namun ada yang bersifat aktif dan ada yang bersifat pasif. Alat tangkap yang tergolong aktif hanya berupa jala (cast net), sedangkan alat tangkap pasif berupa jaring ( gill net) dan bubu (pot trap). Secara lengkap alat tangkap yang digunakan nelayan dalam usaha penangkapan ikan patin ditunjukkan pada Tabel 1

Tabel 1 memperlihatkan bahwa pada semua wilayah tersebut jenis alat yang digunakan hampir sama. Kemudian lokasi penangkapan juga sama pada perairan sungai dan rawa, kecuali untuk wilayah Jawa Barat yang dilakukan di perairan waduk.

\section{Lokasi Sumatera Selatan}

Lokasi usaha penangkapan ikan patin di Sumatera Selatan antara lain dilakukan nelayan di Sungai Musi sekitar Kabupaten Musi Banyuasin di bagian tengah yaitu di Desa Muara Punjung. Alat tangkap yang digunakan adalah jaring yang bersifat pasif yaitu dipasang secara tetap di bagian perairan yang memotong sungai dan diberi pelampung pada bagian atas jaring serta pemberat pada bagian bawah jaring. Kedalaman jaring adalah $5 \mathrm{~m}$ dan panjangnya $40 \mathrm{~m}$ dengan mata jaring 2,5 inchi

Penangkapan ikan patin menggunakan jaring ini dilaksanakan nelayan pada masa air surut yaitu sekitar bulan Mei hingga September dengan lokasi 
Tabel 1. Alat tangkap yang digunakan nelayan untuk menangkap ikan patin di berbagai wilayah di Indonesia Table 1. Fishing gear used by fishers in various region of Indonesia

\begin{tabular}{cll}
\hline No. & \multicolumn{1}{c}{ Propinsi/Province } & \multicolumn{1}{c}{ Jenis Alat Tangkap/Fishing gear } \\
\hline 1 & Sumatera Selatan/South Sumatera & $\begin{array}{l}\text { Jaring, jala dan bubu/gill net, cast net } \\
\text { and pot trap } \\
\end{array}$ \\
2 & Jambi & Jala dan bubu/cast net and pot trap \\
3 & Jawa Barat/West Java & Jala dan jaring/cast net and gill net \\
4 & Kalimantan Selatan/South Kalimantan & Jala/cast net \\
\hline
\end{tabular}

penangkapan di daerah Sungai Musi yang berarus. Ikan yang tertangkap bukan saja ikan patin tetapi juga ikan baung, tapah dan beberapa jenis ikan sungai lainnya seperti lampam dan bengalan. Ukuran ikan yang tertangkap minimum berukuran $0,5 \mathrm{~kg}$ per ekor.

Rata-rata hasil tangkapan nelayan menggunakan jaring ini adalah $5 \mathrm{~kg}$ per hari dengan komposisi hasil tangkapan yang umum didapatkan adalah $40 \%$ ikan patin, 20\% ikan baung, 20\% ikan tapah dan 20\% jenis ikan lainnya. Harga untuk setiap kg ikan patin Rp.18.000,- per kg, ikan baung dan tapah; dan Rp. 15.000,- dan untuk jenis ikan lainnya Rp. 7.000,-Ikan hasil tangkapan langsung dijual kepada pedagang yang membeli ikan nelayan di Sungai Musi. Lalu pedagang ini menjualnya kepada pedagang pengecer di pasar Sekayu (Ibu kota Kabupaten Musi Banyuasin). Adapun jumlah hari kerja nelayan ini adalah 15 hari per bulan atau 75 hari per tahun.

Di lain pihak, usaha penangkapan ikan patin yang menggunakan alat tangkap jala (di daerah setempat disebut jala rambang) antara lain terdapat di Sungai Musi sekitar Kabupaten Musi Banyuasin, di Desa Muara Trawas dan Desa Prajen. Alat tangkap jala ini bersifat aktif yaitu pelaksanaan penangkapan ikan ditujukan pada daerah yang diperkirakan cocok dan ada ikannya. Bahan jala tersebut terbuat dari anyaman tali nilon dengan tinggi 6 meter dan menggunakan tali penggerak pada bagian dalam yang dilengkapi dengan timah pemberat pada bagian bawah, sedangkan mata jaring berukuran 2,5 inchi.

Penangkapan ikan patin menggunakan jala dioperasikan nelayan sepanjang tahun dengan pelaksanaan penangkapan menjelang air surut (air pasang surut) yaitu menjelang air turun pada siang dan sore hari. Ikan yang tertangkap bukan saja ikan patin tetapi juga ikan juaro, baung, si hitam, lampam, kakap dan beberapa jenis ikan sungai lainnya. Ukuran ikan yang tertangkap minimum berukuran 1,0 kg per ekor dengan harga jual ikan patin Rp. 17.000,-- Rp. 19.000 ,- per kg, sedangkan jenis ikan lainnya ratarata $\mathrm{Rp} .7 .000,-$ per $\mathrm{kg}$.
Rata-rata hasil tangkapan nelayan menggunakan jala ini adalah 3-6 kg per hari dengan komposisi hasil tangkapan yang umum didapatkan adalah 50\% ikan juaro, 20\% ikan patin dan 30\% jenis ikan lainnya. Ikan hasil tangkapan langsung dijual kepada pedagang yang membeli ikan nelayan di Sungai Musi. Biaya operasional penangkapan ikan patin menggunakan jala ini meliputi pembelian jala yaitu Rp. 550.000,- per setnya dengan ketahanan sekitar $6-8$ bulan. Pembelian perahu bermotor yang panjangnya 6 meter serta biaya operasional harian.

Usaha penangkapan ikan patin menggunakan perangkap (di daerah setempat disebut bubu Apollo) antara lain terdapat di Sungai Musi bagian tengah di sekitar Danau Cala di Kabupaten Musi Banyuasin. Alat tangkap ini bersifat pasif yaitu pelaksanaan penangkapan ikan ditempatkan pada alur air pada daerah yang diperkirakan cocok dan ada ikannya. Bahan bubu tersebut terbuat dari anyaman rotan dengan diameter sekitar $60-80 \mathrm{~cm}$ dan panjang 2,0 hingga 2,5 meter tergantung kepada keinginan nelayan. Kerapatan anyaman rotan (mesh size) bagian dalam perangkap tersebut sekitar $2 \mathrm{~cm}$.

Penangkapan ikan patin menggunakan bubu ini dioperasikan nelayan sepanjang tahun dengan pelaksanaan penangkapan menjelang air surut atau menjelang air naik. Ikan yang tertangkap bukan saja ikan patin tetapi juga ikan juaro, baung, dan beberapa jenis ikan sungai lainnya. Ukuran ikan yang tertangkap minimum berukuran 0,4 kg per ekor dengan harga jual ikan patin Rp. 14.000,- per kg, sedangkan jenis ikan lainnya rata-rata $\mathrm{Rp} .4 .000$,- per kg.

Hasil tangkapan nelayan menggunakan jala berkisar 2-4 kg per hari dengan komposisi hasil tangkapan yang umum didapatkan adalah $40 \%$ ikan juaro dan baung, 20\% ikan patin, dan 40\% jenis ikan lainnya. Ikan hasil tangkapan langsung dijual kepada pedagang keliling yang membeli ikan nelayan di sekitar Sungai Musi. Biaya usaha penangkapan ikan patin menggunakan bubu meliputi pembelian bubu, pembelian perahu dan biaya operasional harian. 


\section{Lokasi Jawa Barat}

Lokasi usaha penangkapan ikan patin di wilayah Propinsi Jawa Barat antara lain adalah di perairan Waduk Jatiluhur dan Waduk Cirata. Alat tangkap jaring (gill-net) yang bersifat pasif yaitu dipasang secara tetap di bagian perairan waduk yang ada arusnya dan diberi pelampung pada bagian atas jaring serta pemberat pada bagian bawah jaring. Kedalaman jaring adalah 3-4 m dan panjangnya 30-50 m dengan mata jaring sekitar 2,0-2,5 inchi. Penangkapan ikan patin menggunakan jaring dilaksanakan nelayan pada masa menjelang air surut

Ikan yang tertangkap bukan saja ikan patin tetapi juga ikan nila, mujair dan beberapa jenis ikan lainnya seperti nilem. Ukuran ikan yang tertangkap biasanya minimum berukuran 0,3-0,5 kg per ekor. Rata-rata hasil tangkapan nelayan menggunakan jaring ini adalah 1 $3 \mathrm{~kg}$ per hari dengan komposisi hasil tangkapan yang umum didapatkan adalah 20\% ikan patin dan 80\% jenis ikan lainnya. Harga untuk ikan patin adalah Rp. 4.800,- - Rp. 5.100,- per kg dan Rp.3.000,- - Rp. 3.500 per kg untuk jenis ikan lainnya. Adapun jumlah hari kerja nelayan ini berkisar 20 hari per bulan.

Disamping itu, usaha penangkapan ikan patin menggunakan alat tangkap jala (cast net) juga dilakukan nelayan di perairan Waduk Cirata. Alat tangkap jala ini bersifat aktif yaitu pelaksanaan penangkapan ikan ditujukan pada daerah yang diperkirakan cocok dan ada ikannya. Bahan jala tersebut terbuat dari anyaman tali nilon dengan tinggi jala 3-4 meter yang dilengkapi dengan timah pemberat pada bagian bawah, sedangkan mata jaring berukuran 2 inchi.

Penangkapan ikan patin menggunakan jala dioperasikan nelayan sepanjang tahun pada siang dan sore hari. Ikan yang tertangkap bukan saja ikan patin tetapi ikan lainnya yang ada di perairan waduk ini. Rata-rata hasil tangkapan nelayan menggunakan jala adalah 1,5-4 kg per hari dengan komposisi hasil tangkapan yang umum didapatkan adalah 30\% ikan patin dan $70 \%$ jenis ikan lainnya.

\section{Lokasi Kalimantan Selatan dan Jambi}

Lokasi usaha penangkapan ikan patin menggunakan alat tangkap jala untuk wilayah Kalimantan Selatan antara lain perairan rawa di Desa Bangkau dan Sungai Batang Hari untuk wilayah Jambi. Bahan jala tersebut terbuat dari anyaman tali nilon dengan tinggi jala 3-4 meter dan dilengkapi dengan timah pemberat pada bagian bawah, sedangkan mata jaring berukuran 2,0-2,5 inchi

Penangkapan ikan patin menggunakan jala di wilayah Kalimantan Selatan dan Jambi tidak dapat dioperasikan nelayan sepanjang tahun, hanya dilaksanakan pada masa air besar di perairan rawa banjiran. Ikan yang tertangkap bukan saja ikan patin tetapi juga beberapa jenis ikan sungai lainnya. Ukuran ikan yang tertangkap biasanya minimum berukuran 0,5 hingga 1,0 kg per ekor dengan harga jual ikan patin Rp.12.000,- - Rp.13.000,- per kg, sedangkan jenis ikan lainnya rata-rata Rp.4.000,-per kg.

Hasil tangkapan nelayan menggunakan jala berkisar 1-2 kg per hari dengan komposisi hasil tangkapan yang umum didapatkan adalah 60\% ikan patin dan $40 \%$ jenis ikan lainnya. Biaya usaha penangkapan ikan patin menggunakan jala ini meliputi pembelian jala, pembelian perahu serta biaya operasional harian

Usaha penangkapan ikan patin menggunakan bubu Apollo (rattan trap) dilakukan nelayan di perairan Sungai Kumpeh, sekitar Desa Arang-Arang, Kabupaten Batang Hari, Propinsi Jambi. Alat tangkap ini bersifat pasif yang ditempatkan pada alur air pada daerah yang diperkirakan akan dilalui ikan. Bahan bubu tersebut terbuat dari anyaman rotan dengan diameter sekitar $60-70 \mathrm{~cm}$ dan panjang 1,5 hingga 2,5 meter tergantung kepada keinginan nelayan. Juga dilengkapi dengan perangkap sebagai jalan masuknya ikan ke dalam bubu tersebut, sedangkan kerapatan (mesh size) anyaman rotan 1,5-2 cm.

Penangkapan ikan patin menggunakan bubu dioperasikan nelayan sepanjang tahun dengan pelaksanaan penangkapan menjelang air surut atau menjelang air naik (air sungai dipengaruhi gerakan pasang surut air laut). Ikan yang tertangkap bukan saja ikan patin tetapi juga ikan baung, toman, dan beberapa jenis ikan sungai lainnya. Ukuran ikan yang tertangkap biasanya minimum berukuran 0,3 kg per ekor. Harga jual ikan patin biasanya Rp. 13.000,- per kg, sedangkan jenis ikan lainnya rata-rata Rp. 4.500, per kg. Jumlah hasil tangkapan nelayan menggunakan jala dengan jumlah hari kerja sekitar 15 hari per bulan adalah $38 \mathrm{~kg}$ ikan patin dan $34 \mathrm{~kg}$ ikan lainnya. Ikan hasil tangkapan langsung dijual kepada pedagang di sekitar desa tersebut

Kemudian dapat dijelaskan pula bahwa pada semua jenis alat tangkap dan semua wilayah riset, nelayan sebagai penangkap ikan dalam mengambil keputusan untuk menangkap ikan patin tidak secara sendiri-sendiri. Tetapi dominan dipengaruhi oleh temantemannya sesama nelayan terutama mengikuti mereka yang telah berpengalaman terlebih dahulu. Dalam hal ini terutama untuk penentuan lokasi penangkapan, jenis alat tangkap yang digunakan pada lokasi tersebut, dan saat yang tepat untuk melaksanakan usaha penangkapan ikan patin

Nelayan memilih komoditas ikan patin ini karena harganya yang cukup tinggi dibandingkan dengan jenis 
ikan hasil tangkapan lainnya. Namun demikian, dari segi pendapatan nelayan, sebenarnya alat tangkap ini bukan merupakan alat tangkap utama yang digunakan nelayan untuk menopang kehidupannya. $\mathrm{Hal}$ ini antara lain sebagai akibat pola penangkapan ikan patin yang bersifat musiman sesuai dengan pola ruaya ikan tersebut di alam sehingga secara individu tidak terdapat perencanaan usaha untuk penangkapan ikan patin ini.

Teknologi yang digunakan dalam usaha penangkapan ikan patin ini tergolong sederhana dan oleh karenanya digolongkan kepada usaha perikanan secara tradisional. Hal ini didukung pula ciri lainnya seperti usaha penangkapan ikan yang dijalankan secara sendiri-sendiri dan atau hanya bersama keluarga. Operasional penangkapan ikan patin umumnya dilakukan menggunakan perahu tanpa motor. Khusus untuk alat tangkap bubu apollo merupakan rakitan sendiri yang bahan bakunya tersedia secara lokal. Disamping itu, tingkat pendidikan, keterampilan dan penerimaan mereka terhadap inovasi juga rendah

\section{Analisis Finansial Usaha}

Analisis finansial usaha penangkapan ikan patin menggunakan jaring, jala dan bubu di Sumatera Selatan berdasarkan biaya operasional dan penerimaan yang didapatkan pada masing-masing usaha penangkapan serta perhitungan RC Ratio secara ringkas diperlihatkan pada Tabel 2

Tabel 2 menggambarkan bahwa investasi yang dikeluarkan untuk usaha penangkapan ikan patin menggunakan alat tangkap jaring, jala dan bubu di wilayah Sumatera Selatan tidak jauh berbeda satu sama lain. Namun semua alat tangkap ini tidak spesifik hanya ditujukan untuk menangkap ikan patin. Artinya alat tangkap tersebut tergolong tidak selektif untuk menangkap jenis ikan tertentu. Terlihat bahwa alat tangkap yang paling efisien dalam menangkap ikan patin adalah bubu, sedangkan tingkat efisiensi

Tabel2. Nilai investasi, biaya tetap, biaya operasional, penerimaan usaha dan keuntungan usaha penangkapan ikan patin di Sumatera Selatan, Tahun 2002

Table 2. Invesment value, fixed cost, variable cost, revenue and profit of catfish capture fishery in South Sumatera, 2002

\begin{tabular}{lccc}
\hline & \multicolumn{3}{c}{ Alat Tangkap/Fishing Gear } \\
\cline { 2 - 4 } \multicolumn{1}{c}{ Uraian/Item } & $\begin{array}{c}\text { Jaring/Gill-net } \\
\text { (Rp/bulan) } \\
\text { (Rp/month) }\end{array}$ & $\begin{array}{c}\text { Jala/Cast net } \\
\text { (Rp/bulan) } \\
\text { (Rp/month) }\end{array}$ & $\begin{array}{c}\text { Bubu Apollo } \\
\text { /Rattan Trap } \\
\text { (Rp/bulan) } \\
\text { (Rp/month) }\end{array}$ \\
\hline Investasi//nvesment & 2.200 .000 & 2.050 .000 & 1.850 .000 \\
Biaya Tetap/Fixed cost & 216.650 & 188.300 & 261.500 \\
Biaya Operasional/Variable cost & 180.000 & 200.000 & 110.000 \\
Total Biaya/Total cost & 396.650 & 388.300 & 371.600 \\
Penerimaan Total/Total revenue & 1.095 .000 & 710.000 & 640.000 \\
Penerimaan Patin/Revenue from catfish & 540.000 & 480.000 & 560.000 \\
Keuntungan Usaha Total/Total profit & 915.000 & 510.000 & 530.000 \\
Keuntungan Usaha Patin/Profit from catfish & 360.000 & 280.000 & 450.000 \\
RC Ratio Usaha Total/Total RC Ratio & 2,76 & 1,83 & 1,72 \\
RC Ratio Usaha Patin/RC Ratio for catfish & 0,91 & 1,24 & 1,51 \\
\hline
\end{tabular}


ekonomi secara total yang digambarkan dengan RC Ratio terdapat pada alat tangkap jaring

Analisis finansial usaha penangkapan ikan patin di Jawa Barat berdasarkan biaya operasional dan penerimaan yang didapatkan baik yang terdapat di Waduk Jatiluhur maupun Waduk Cirata secara ringkas diperlihatkan pada Tabel 3.

Tabel 3 menggambarkan bahwa investasi yang dikeluarkan untuk usaha penangkapan ikan patin menggunakan alat tangkap jaring dan jala di dua waduk tersebut tidak jauh berbeda satu sama lain. Kemudian, kedua alat tangkap ini juga tidak spesifik hanya ditujukan untuk menangkap ikan patin. Artinya utama yang digunakan nelayan untuk menopang kehidupannya.

Analisis finansial usaha penangkapan ikan patin menggunakan jala dan bubu di wilayah Kalimantan Selatan dan Jambi diperlihatkan pada Tabel 4.

Tabel 4 menggambarkan bahwa investasi yang dikeluarkan untuk usaha penangkapan ikan patin menggunakan alat tangkap jala di dua wilayah tersebut jauh berbeda satu sama lain. Namun kedua alat tangkap ini juga tidak spesifik hanya ditujukan untuk menangkap ikan patin. Artinya alat tangkap tersebut juga tergolong tidak selektif. Terlihat bahwa untuk alat tangkap yang sama, efisiensi yang tinggi terdapat pada

Tabel 3. Nilai investasi, biaya tetap, biaya operasional, penerimaan usaha dan keuntungan usaha penangkapan ikan patin di Jawa Barat, Tahun 2002

Table 3. Invesment value, fixed cost, variable cost, revenue and profit of catfish capture fishery in West Java, 2002

\begin{tabular}{|c|c|c|c|}
\hline \multirow[b]{2}{*}{ Uraian/ltem } & \multicolumn{3}{|c|}{ Alat Tangkap/Fishing Gear } \\
\hline & $\begin{array}{c}\text { Jaring di Waduk } \\
\text { Jatiluhur/Gill net } \\
\text { in Jatiluhur } \\
\text { reservoir } \\
\text { (Rp/bulan) } \\
\text { (Rp/month) }\end{array}$ & $\begin{array}{c}\text { Jaring di } \\
\text { Waduk Cirata/ } \\
\text { Gill net in } \\
\text { Cirata reservoir } \\
\text { (Rp/bulan) } \\
\text { (Rp/month) }\end{array}$ & $\begin{array}{c}\text { Jala di Waduk } \\
\text { Cirata/Cast net } \\
\text { in Cirata } \\
\text { reservoir } \\
\text { (Rp/bulan) } \\
\text { (Rp/month) }\end{array}$ \\
\hline Investasi/Invesment & 800.000 & 1.250 .000 & 1.500 .000 \\
\hline Biaya Tetap/Fixed Cost & 133.300 & 212.500 & 200.000 \\
\hline Biaya Operasional/Variable cost & 240.000 & 160.000 & 200.000 \\
\hline Total Biaya/Total cost & 373.300 & 372.500 & 400.000 \\
\hline Penerimaan Total/Total revenue & 678.000 & 249.500 & 466.700 \\
\hline Penerimaan Patin/Revenue from catfish & 153.000 & 96.000 & 186.200 \\
\hline Keuntungan Usaha Total/Total profit & 438.000 & 89.500 & 266.700 \\
\hline Keuntungan Usaha Patin/Profit from catfish & -87.000 & -64.000 & -13.800 \\
\hline RC Ratio Usaha Total/Total RC Ratio & 1,82 & 0,67 & 1,17 \\
\hline RC Ratio Usaha Patin/RC Ratio for catfish & 0,41 & 0,26 & 0,47 \\
\hline
\end{tabular}

alat tangkap tersebut juga tergolong tidak selektif. Terlihat bahwa alat tangkap yang paling banyak menghasilkan ikan patin dan secara ekonomi lebih efisien (RC Ratio) adalah alat tangkap jaring di Waduk Jatiluhur. Dari segi pendapatan nelayan, sebenarnya alat tangkap ini juga bukan merupakan alat tangkap wilayah Jambi baik secara keseluruhan hasil tangkapan maupun untuk ikan patin saja.

Dari segi pendapatan nelayan, sebenarnya alat tangkap ini bukan merupakan alat tangkap utama yang digunakan nelayan untuk menopang kehidupannya. Nelayan menopang kehidupannya dari 
Tabel 4. Nilai investasi, biaya tetap, biaya operasional, penerimaan usaha dan keuntungan usaha penangkapan ikan patin di Kalimantan Selatan dan Jambi, Tahun 2002

Table 4. Invesment value, fixed cost, variable cost, revenue and profit of catfish capture fishery in South Kalimantan and Jambi, 2002

\begin{tabular}{lccc}
\hline & \multicolumn{3}{c}{ Alat Tangkap/Fishing Gear } \\
\cline { 2 - 4 } \multicolumn{1}{c}{ Uraian/ltem } & $\begin{array}{c}\text { Jala di } \\
\text { Kalsel/Cast net in } \\
\text { South Kalimantan } \\
\text { (Rp/bulan) } \\
\text { (Rp/month) }\end{array}$ & $\begin{array}{c}\text { Jambi/Cast net } \\
\text { in Jambi } \\
\text { (Rp/bulan) } \\
\text { (Rp/month) }\end{array}$ & $\begin{array}{c}\text { Bambi/Pot trap } \\
\text { in Jambi } \\
\text { (Rp/bulan) } \\
\text { (Rp/month) }\end{array}$ \\
\hline Investasi//nvesment & 2.700 .000 & 1.650 .000 & 2.050 .000 \\
Biaya Tetap/Fixed cost & 258.300 & 225.000 & 370.000 \\
Biaya Operasional/Variable cost & 240.000 & 260.000 & 127.500 \\
Total Biaya/Total cost & 498.300 & 485.000 & 497.500 \\
Penerimaan Total/Total revenue & 668.000 & 920.000 & 647.000 \\
Penerimaan Patin/Revenue from catfish & 540.000 & 780.000 & 494.000 \\
Keunntungan Usaha Total/Total profit & 428.000 & 660.000 & 519.500 \\
Keuntungan Usaha Patin/Profit from catfish & 300.000 & 520.000 & 366.500 \\
RC Ratio Usaha Total/Total RC Ratio & 1,34 & 1,9 & 1,3 \\
RC Ratio Usaha Patin/RC Ratio for catfish & 1,08 & 1,61 & 0,99 \\
\hline
\end{tabular}

hasil tangkapan menggunakan berbagai jenis alat tangkap dan ditambah pula dengan kegiatan budidaya ikan dalam skala kecil. Begitu juga untuk alat tangkap bubu apollo yang menghasilkan ikan patin dan beberapa jenis ikan lainnya. Di samping itu, diperlihatkan pula bahwa penerimaan usaha untuk ikan patin pada alat tangkap bubu cukup tinggi jika dibandingkan dengan penerimaan total untuk seluruh jenis ikan yang tertangkap. Artinya pada alat tangkap bubu, ikan patin merupakan hasil tangkapan dominan yang dihasilkan nelayan.

Sebelum ikan hasil tangkapan dijual, tidak ada usaha yang ditujukan terhadap pengendalian hama dan penyakit. Juga tidak ada perencanaan dalam pengaturan penangkapan dan mereka belum mengetahui perlunya pengaturan tersebut, termasuk belum adanya pengaturan untuk pasca panen kecuali terbatas kepada usaha untuk menjaga agar ikan tetap hidup sebelum dijual kepada pedagang menggunakan wadah ikan berupa kantong jaring yang dihanyutkan di perairan sambil berperahu. Juga belum ada pengaturan pemasaran guna mempertahankan harga ikan patin hasil tangkapan.

\section{Aspek Kelembagaan}

Belum terdapat pengorganisasian nelayan yang melaksanakan dan mengelola usaha penangkapan ikan patin yang ditetapkan oleh pemerintah setempat untuk tujuan pembinaan kearah peningkatan dan atau pengaturan usaha penangkapan dan pemasaran ikan hasil tangkapan. Kemudian juga tidak ditemui adanya perencanaan usaha oleh masyarakat nelayan dan belum tersedia bantuan fasilitas modal ataupun perkreditan untuk nelayan penangkap ikan patin.

Dalam hal akses pasar juga belum ditemui adanya lembaga yang berfungsi sebagai fasilitator harga. Kelembagaan yang terlibat dalam pemasaran ikan patin antara lain pedagang yang berada di sekitar wilayah perairan yang melakukan pembelian ikan hasil tangkapan nelayan atau dibeli oleh pedagang di perairan tempat usaha penangkapan dilakukan 
Penentuan harga hanya dilakukan sepihak oleh pedagang yang membeli, meskipun tidak ada keterikatan nelayan dalam pengadaan sarana produksi yang mereka gunakan

Sistem pembayaran dilakukan secara tunai dengan biaya pemasaran ke wilayah konsumen di pasar dibebankan terhadap pedagang yang membeli ikan hasil tangkapan nelayan tersebut. Akhirnya kenaikan harga yang terjadi pada konsumen tidak selalu diketahui oleh nelayan penangkap ikan, sedangkan jika harga turun selalu ada informasi dari pedagang tersebut.

Hasil akhir yang didapatkan nelayan berhubungan erat dengan alat tangkap utama yang mereka laksanakan dan keahlian mereka dalam menentukan daerah penangkapan (fishing ground). Bahkan untuk nelayan di wilayah Waduk Cirata, dan Jatiluhur Jawa Barat, pekerjaan utama mereka adalah berfungsi sebagai pelaksana pembudidaya ikan dengan sistem keramba jaring apung atau mereka juga bekerja sebagai buruh angkut ikan jika pada saat pelaksanaan panen ikan hasil budidaya di suatu tempat tertentu di sekitar tempat tinggal mereka. Dalam hal ini, menangkap ikan patin ataupun menangkap ikan menggunakan alat tangkap seperti jaring atau jala bukan merupakan pekerjaan utama mereka dan hal ini akan mengurangi semangat kewirausahaan (entepreneurship) nelayan tersebut dalam usaha penangkapan ikan.

Kebijakan pemerintah setempat dapat dikategorikan belum mendukung ke arah berkembangnya sistem usaha perikanan penangkapan ikan patin. Hal ini terlihat bahwa untuk semua wilayah riset, komoditas ikan patin tidak menjadi prioritas untuk dikembangkan dan ataupun dilestarikan. Nelayan yang melaksanakan usaha penangkapan ikan patin, juga belum dibina secara maksimal misalnya dikelompokkan, diberi pengarahan/ penyuluhan, diberi bantuan modal dan atau pinjaman modal untuk berusaha dalam hubungannya dengan pengaturan musim penangkapan ataupun tempat penangkapan serta penanganan pasca panen ikan tersebut.

\section{KESIMPULAN DAN SARAN}

Usaha perikanan penangkapan ikan patin yang terdapat di masyarakat saat ini, berdasarkan tahap perkembangan teknologi berusaha secara umum hampir sama untuk seluruh wilayah riset yaitu jaring dan jala, hanya wilayah Sumatera Selatan dan Jambi terdapat tambahan jenis alat tangkap yaitu bubu Apollo (rattan trap). Kemudian, semua alat tangkap yang digunakan tidak khusus digunakan untuk menangkap ikan patin bahkan untuk perairan Waduk
Jatiluhur dan Cirata ikan patin hasil tangkapan lebih sedikit jika dibandingkan dengan jenis ikan lainnya. Hal ini berhubungan erat dengan alat tangkap utama yang mereka laksanakan dan keahlian mereka dalam menentukan daerah penangkapan (fishing ground) Meskipun secara finansial usaha penangkapan ikan patin masih menguntungkan tetapi nilai RC Ratio yang didapatkan khusus untuk ikan patin lebih kecil dari satu.

Peluang pengembangan perikanan penangkapan pada prinsipnya ditinjau dari aspek teknik lingkungan untuk semua wilayah baik di Sumatera Selatan, Jambi dan Kalimantan Selatan maupun Jawa Barat masih memungkinkan. Hal ini didasarkan atas besarnya potensi lahan berupa perairan yang dapat difungsikan sebagai tempat hidup dan kehidupan ikan patin di alam. Namun demikian, pengkayaan stok merupakan salah satu usaha untuk meningkatkan populasi ikan patin tersebut perlu pula dilakukan

Ditinjau dari aspek sosial dan budaya pengembangan lebih diutamakan pada wilayah Sumatera Selatan, Jambi dan Kalimantan Selatan karena ikan patin, terutama patin lokal sangat disukai masyarakat di wilayah tersebut sebagai ikan konsumsi. Saran lainnya yang diperlukan dalam rangka pengembangan usaha perikanan penangkapan ikan patin adalah bantuan modal bagi usaha penangkapannya. Disamping itu, perlu pula pengorganisasian nelayan terutama dalam hubungannya dengan pemasaran hasil.

\section{DAFTAR PUSTAKA}

Aeron-Thomas, M., Garaway, C., Hoggarth, D.D. Koeshendrajana, S., Nasution, Z. and Sarnit, S. 1998, Regional Reserves Survai Report, Central Research Institute for Fisheries and Provincial Fisheries Services, Indonesia and Marine Resource Assessment Group Ltd., United Kingdom.

Cochran, W.G. 1977. Sampling Techniques, John Wiley and Sons, Inc. New York.

Goenadi, D.H. 2000, 'Pengalaman Pemasaran Teknologi Pertanian Bernilai Komersial', KIAT. Bogor. 14 pp.

Hadie, L.E. dan Hadie, W. 2000, Manajemen keragaman genetik dalam mendukung konservasi ikan secara ex-situ, Seminar Nasional Keanekaragaman Hayati Ikan. Pusat Studi IImu Hayati. LP-IPB dan Puslitbang Biologi LIPI, Bogor. 9 pp

Koeshendrajana, S. 1997, Management Options for the Inland Fisheries Resource in South Sumatra, Indonesia, PhD thesis, University of New England, Armidale, NSW, Australia.

Nazir, Moh., 1988. Metode Penelitian. Ghalia Indonesia, Jakarta.

Saragih, B. 2001a. AGRIBISNIS Paradigma Baru Pembangunan Ekonomi Berbasis Pertanian. Yayasan Mulia Persada Indonesia dan PT. Surveyor 
Indonesia bekerjasama dengan PSP IPB dan ESESE Fondation. Jakarta.

Saragih, B. 2001b. Membangun Keunggulan Kompetitif Berdasarkan Keunggulan Komparatif; Suara dari Bogor Membangun Sistem Agribisnis. Yayasan
USESE bekerjasama dengan Sucofindo, Jakarta. p.109-112.

Singarimbun, M. dan Effendi, S. 1989. Metode Penelitian Survai. LP3ES. Jakarta. 


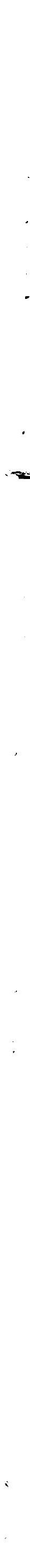

